\title{
Repeat Object
}

National Cancer Institute

\section{Source}

National Cancer Institute. Repeat Object. NCI Thesaurus. Code C48804.

Something occurring more than once. 